\title{
108 加工ループの安定性解析と高速電極駆動ヘッドによる加工の高速化
}

Analysis of Stability of EDM Machining Loop

and Improvement of Machining Speed by Using High Speed Actuator

$$
\begin{aligned}
& \text { ○正 家澤 雅宏 (三菱電機) 正 今城 昭彦 (三菱電機) } \\
& \text { 赤松 浩二(三菱電機）鈴木 智 (三菱電機エンジニアリング) }
\end{aligned}
$$

Masahiro IEZAWA,Mitsubishi Electric Corp.,8-1-1,Tsukaguchi honmachi,Amagasaki city, Hyogo Akihiko IMAGI,Mitsubishi Electric Corp.

Koji AKAMATSU,Mitsubishi Electric Corp.

Satoshi SUZUKI,Mitsubishi Electric Engineering Co.Ltd.

In this paper, we investigated the stability of EDM machining loop using a high speed actuator. The stability condition of machining loop was obtained by describing function analysis. We performed the test of electric discharge machining and it was confirmed that the result of experiment were in good agreement with the result of simulation.

Key Words. Servo mechanism, Stability, Electrical Discharge Machining

\section{1.はじめに}

放電加工機において、加工制御系の高速化は加工速度の向 上のために不可欠であり、従来よりボイスコイルモー夕や圧 電素子を用いた電極駆動装置が加工速度の改善に有効であ ることが報告されている

本研究では、高速電極駆動装置の応答性能が加工制御系の 安定性にどのように寄与するかを明らかにするために、非線 形制御理論に扮计る記述関数法を用いて解析し、そ0妥当性 をシミュレーションと実験で検証した。次に、細穴加工用電 極を用いて加工実験を行い、高速駆動装置による加.厂.速度の 改善効果を確認したので、以下にその内容を報告する。

\section{2. 放電加工制御系の構成}

本研究における実験装置の構成を図1に示す。Z軸方向の 一軸テーブル上に高速電極駆動装置を取り付け、一軸テーブ ルと高速電極駆動装置の協調動作によって電極・ワーク間の 極間距離を制御する。駆動制御は、それぞれの位置センサー からの信号と NC 装置からの極間平均電压信号をもとにし て、アンプを介してパソコン上で制御する。

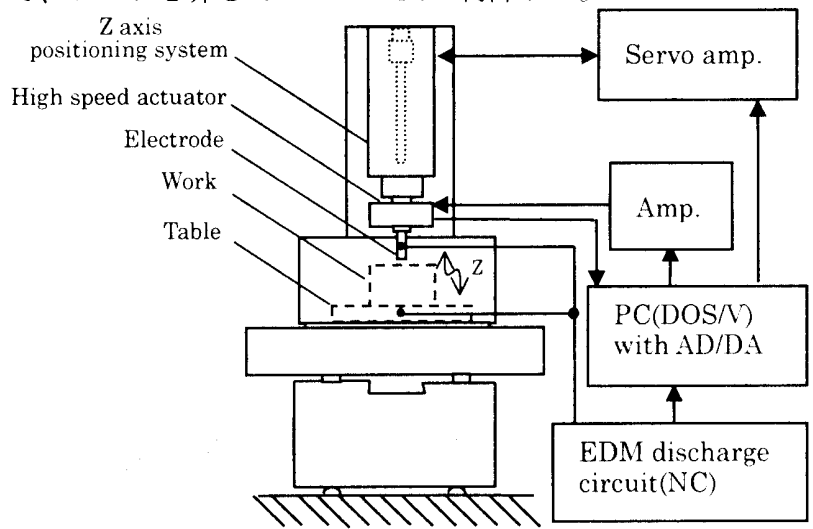

図 1 実験装置の構成

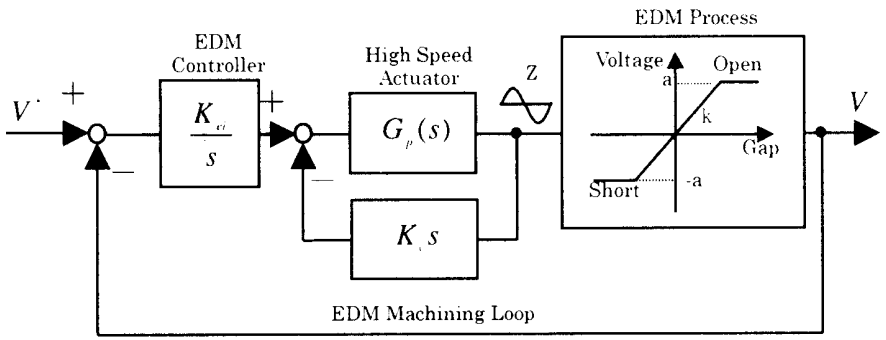

図 2 加工制御采の構成
次に、加工制御系のブロック線図を図 2 に示す。伝達関数 $G_{r}(s)$ の電極駆動装置の外側に電極位置をフイードバックす る速度ループと極間平均電压をフィードバックする加工ル ーブを設けている。電極駆動装置の電流制御系の伝達関数は 1、電極・ワーク間の距離（極間隙間）と極間平均電圧の関 係は飽和要素として近似している。また、実際の電極駆動装 置は一軸デーブルとの協調制御を抗こなっているが、一軸テ ーブルのストロークが加工を安定に保つ意味で十分であり、 その応答性も一軸テーブルに比べて十分速いものとして、こ こではその動特性は無視している。

\section{3. 加工制御系の安定性解析}

速度ルーブを含めた電極駆動装置の動特性を次の二次采 とみなして加工ループの安定性を解析する。

$$
G_{p}(s)=\frac{(1 / K) \omega_{r}^{2}}{s^{2}+2 \zeta_{p} \omega_{p} s+\omega_{p}^{2}}
$$

ここで、 $1 / K$ は電極駆動装置の剛性、 $\omega_{\nu}$ は固有振動数、 $\zeta_{p}$ は減衰比である。

図 2 の加工制御系は駆動系の線形要素と放電加工現象の 非線形要素からなるので、ここでは非線形制御理論における 記述関数法を用いて解析する。

飽和要素の記述関数は次式で表される。

$$
N(A)=\frac{2 k}{\pi}\left[\operatorname{Sin}^{-1} \frac{a}{A}+\frac{a}{A} \sqrt{1-\frac{a^{2}}{A^{2}}}\right]
$$

ここで、Aは発振状態における正弦波振幅、 $k$ は飽和要素に おける比例部分の傾き、 $a$ は飽和要素の上限値である。

式(1)、(2)より、次式を満たすような $\omega$ が存在するとき、 加工制御采は発振する。

$$
\frac{K_{c}}{j \omega} \cdot \frac{(1 / K) \omega_{p}^{2}}{s^{2}+\left(2 \zeta_{n}+K / K\right) \omega_{r} s+\omega_{\mu}^{2}} \cdot N(A)+1=0
$$

ここで、 $K$ は加工制御器の積分ゲインである。

式(3)方解を持つためには、少なくとも $\omega=\omega_{\mu}$ である必要があり、これが加工ループの発振周波数である。

なお、加工ループの発振状態に扮ける電極駆動装置の振動 変位は $Z=A \sin \omega_{t} t$ である。

次に、加工制御系の安定条件を導く。 $\omega=\omega_{p}$ を式(3)に代 入して、 


$$
\frac{2 k}{\pi}\left[\operatorname{Sin}^{-1} \frac{a}{A}+\frac{a}{A} \sqrt{1-\frac{a^{2}}{A^{2}}}\right]=\frac{\left(2 \varsigma_{p} \omega_{p}+K_{v} / K\right) \omega_{p}}{K_{e i} / K}
$$

が得られる。式(4)の等式は、加工ループの発振条件である から、この等式が成り立たないときに加工ループは安定であ る。このことから、加工ループの安定条件は、

$$
\left|\frac{a}{A}\right|>1 、 K_{e i}<\frac{\left(2 \zeta_{p}+K / K\right) \omega_{p}}{k / K}
$$

となる。加エループが安定であるためには上式のいずれかを 満足すればよい。

式(5)において、第 1 式は極間平均電圧が線形な領域でワ 一クと電極との距離を維持しつづけることを示しているが、 実際の加工では加工くずなどの外乱が存在するため、放電位 置を常に線形領域に維持するのは難しいことと、加工を安定 に維持するには加工くずを排出するためにある程度の電極 移動量が必要であることから、第 2 式が加工制御系の安定条 件になる。この条件によれば、電極駆動装置の固有振動数と 速度フィードバックゲインを大きくすることによって、安定 な加工制御采が得られることを示しているい"。

\section{4.シミュレーションと実験による検証}

電極駆動装置の力指令值から電極位置までの周波数伝達 特性を図 3 に示す。実線が実験結果、破線がシミュレーショ ン結果である。約 $180 \mathrm{~Hz}$ の急峻なピークがあり、これが電 極駆動装置の固有振動数である。

次に、電極位置の擬似微分による速度フィードバックを行 ったときの力指令值から電極位置までの周波数伝達特性を 図 4 に示す。実験とシミュレーションはよく一致しており、 速度フィードバックによってゲインピークが抑制されてい ることが確認できる。なお、式(5)によれば、速度フィード バックゲインを大きくすれば加工ループの安定性恃増すが、 過剩な速度フィ一ドバックは極間平均電圧指令への追従性 を少化させるとともに、センサーノイズによる速度フィード バックループの不安定をまねくため、ここでは系の減衰比が 0.7 なるように速度フイードバックゲインを設定した。

以上のように調整した電極駆動装置を図1の装置に組み 込み、加工制御系の応答を確認した。加工制御器の積分ゲイ ンを安定限界以上に大きくしたときの極間平均電圧と電極 駆動装置の電極位置の時間波形を図 5 に示す。図の(a)がシ ミュレーション結果、图の(b)が実測結果である。シミュレ ーション結果と実測結果ともに、加工制御柔の発振周波数は $165 \mathrm{~Hz}$ であり、図 3 の固有振動数とほぼ-致していること が確認できる。

最後に、 $\phi 0.1 \mathrm{~mm}$ のタングステン電極を用いて、材質 SKS11、板厚 $1 \mathrm{~mm}$ の加工を行ったときの極間平均電压の時 間波形の実測結果を図 6 に示す。加工制御器の積分ゲインは、 式(5)を満たす範囲で適当に調整した。一軸テーブルのみの 場合に比べて、電極駆動装置は連続して安定な放電加工を維 持できている。加工速度を測定すると、一軸テーブルのみの ときの 29 秒に対して、電極駆動装置ありでは 11 秒と 2 倍 以上高速化できることを確認した。

\section{5。まとめ}

本研究では、記述関数法を用いて加エループの安定条件を 明らかにし、シミュレーションと実験で検証した結果、理論 と実験がよく一致することを確認した。次に、申0.1 mm の タングステン電極を用いて加工実験を行い、一軸テーブルの みに比べて、電極駆動装置ありでは 2 倍以上高速化できるこ とを確認した

\section{参考文献}

(1)増沢他、電機加工学会誌、Vol.8、No.16、(1975)、43-52.

(2)今井他、電機加工学会誌、Vol.27、No.55、(1993)、23-30.

(3)J.E.Slotine et al. Applied Nonlinear Control、Prentice Hall.

(4)今城他、機論、63-609、C(1997)、1476-1483.
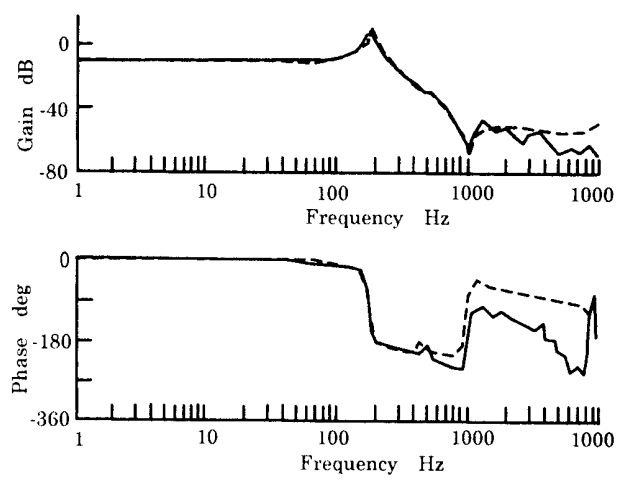

図 3 力指令值から電極位置までの周波数伝達特性
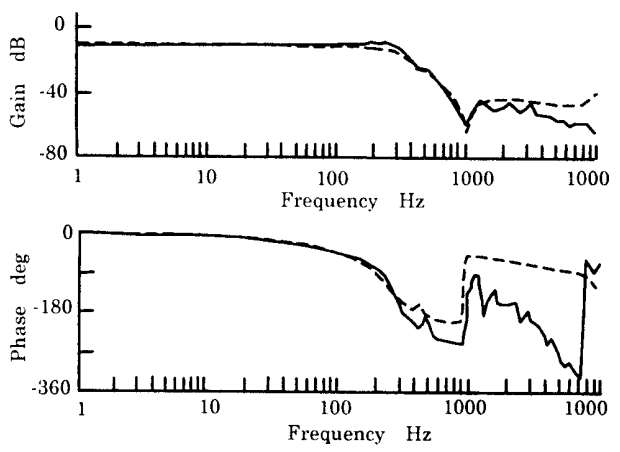

図 4 速度フィ一ドバック後の周波数伝達特性
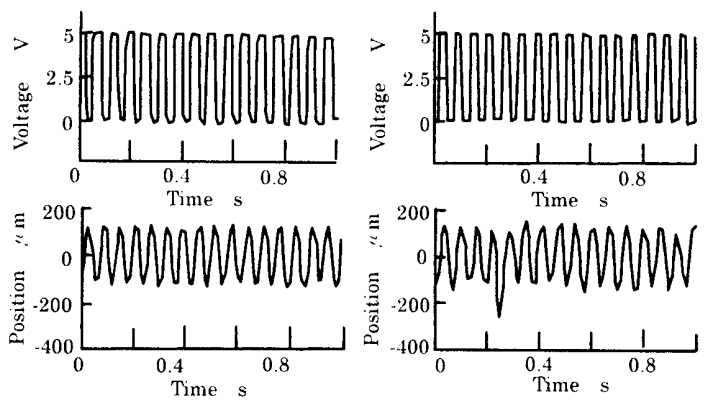

(a)シミュレーション

(b) 実測

図 5 極間平均電压と電極位置の時間波形
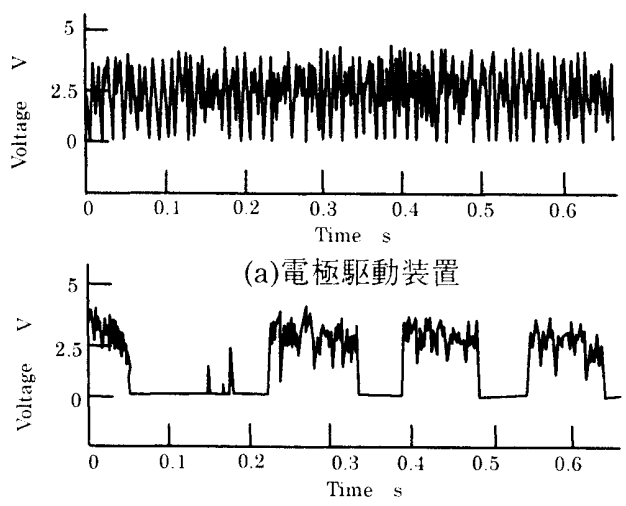

(b)一軸テーブルのみ

闵 6 加工中の極間平均電圧の時間波形 